\title{
PENGUNGKAPAN CORPORATE SOCIAL RESPONSIBILITY BIDANG PENDIDIKAN DALAM LAPORAN TAHUNAN BANK UMUM SYARIAH DI INDONESIA
}

\author{
Mutiara Intan Permana Gunawan dan Ahmad Tarmizi Lbs \\ Program Studi Akuntansi Syariah \\ Sekolah Tinggi Ekonomi Islam SEBI \\ Email: mutiaraintanp@yahoo.com
}

\begin{abstract}
This research is a descriptive study that aims to understand the suitability of the intent and purpose of CSR education disclosure in annual reports Islamic Bank in Indonesia. The annual reports used in this study is the annual report of iB in Indonesia in 2013 and 2014. This study uses content analysis as a tool of analysis, which counting and classifying sentences / phrases that are disclosed in accordance with the categories specified. The results showed that the BUS in Indonesia are still not yet optimal in disclose of CSR education. This is because there is only one iB that able to reveal CSR education optimally in accordance with the intent and the main purpose, without tucking other interests in it. While on the other Islamic banks are still been increase and decrease in the level of suitability in intent and the purpose of disclosure. But in a broad outline, in two years the majority of Islamic banks has an increase levels of suitability for intent and purpose disclosure of CSR education despite the increase not happen drastically.
\end{abstract}

Keywords: disclosure, education, corporate social responsibility, annual report, content analisys

\section{PENDAHULUAN}

Motivasi utama setiap perusahaan yang menjalankan aktivitas bisnis tentunya adalah mencari keuntungan. Keuntungan yang semakin meningkat menandakan perusahaan tersebut semakin berkembang. Hal ini yang menjadi mimpi dan harapan para pimpinan serta jajaran perusahaan. Namun realitanya, banyak perusahaan yang bukan hanya semakin kaya tetapi juga semakin berkuasa, sementara penduduk miskin dan lemah serta rentan secara sosial, ekonomi, politik, kesehatan dan lingkungan semakin banyak.Dari situlah akhirnya timbul kesenjangan sosial antara si miskin dan si kaya. Fenomena yang sudah menjadi masalah klasik di Indonesia seperti dalam grafik 1.

Rasio gini merupakan ukuran ketidakmerataan atau ketimpangan agregat (secara keseluruhan) yang angkanya berkisar antara nol (pemerataan sempurna) hingga satu (ketimpangan yang sempurna). Dapat dilihat dalam grafik di atas bahwa dalam 6 tahun terakhir rasio gini di Indonesia semakin meningkat. Artinya, ketimpangan atau ketidakmerataan pendapatan di Indonesia semakin mendekati sempurna. 
Grafik 1. Tingkat Ketimpangan Agregat di Indonesia

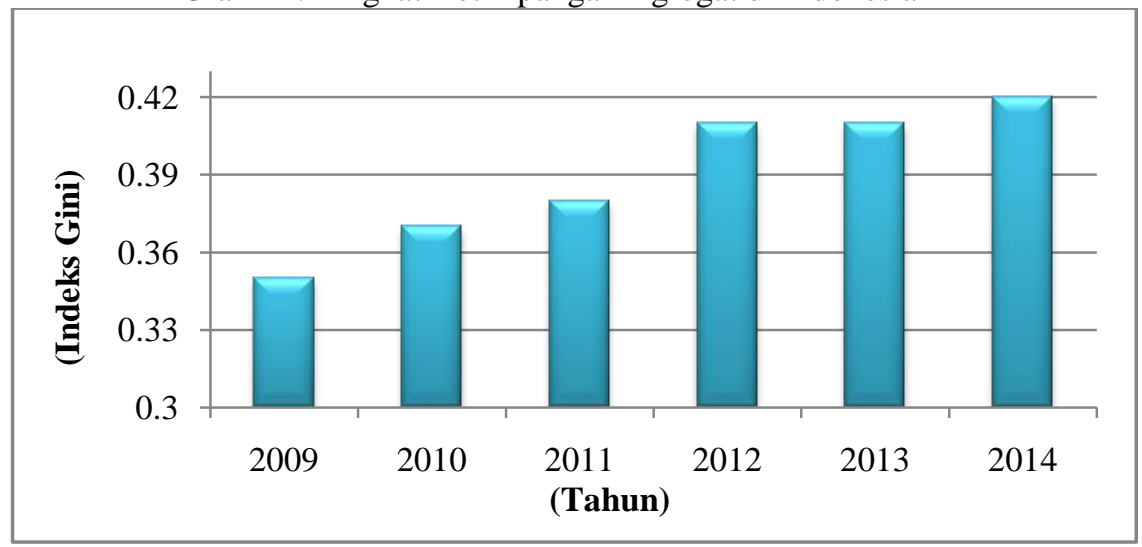

Sumber: BPS, data diolah.

Untuk mengantisipasi tingkat kesenjangan atau ketidakmerataan pendapatan yang semakin memburuk, pihak manajemen beserta jajarannya perlu memperhatikan segala aspek dalam mengembangkan perusahaannya. Perusahaan dapat hidup dan berkembang tidak lepas dari dua hal, yaitu: (1) Peran pemerintah yang telah membangun infastruktur, regulasi yang menguntungkan, kemudahan serta terciptanya iklim bisnis yang kondusif. (2) Masyarakat sekitar perusahaan, baik yang terlibat langsung di perusahaan seperti buruh atau karyawan perusahaan, maupun yang tidak terlibat langsung telah menciptakan kondisi yang kondusif sehingga perusahaan merasa tenang dalam menjalankan bisnisnya (Sopyan, 2014).

Hal tersebut secara tidak langsung menerangkan bahwa agar perusahaan dapat hidup dan berkembang, maka perusahaan seharusnya tidak hanya memiliki tanggung jawab terhadap stockholder saja, tapi juga stakeholder secara keseluruhan. Konsep seperti ini disebut triple bottom line oleh John Elkington dalam bukunya yaitu Cannibals With Forks: The Triple Bottom Line in 21st Century Business (1998). Elkington menjelaskan bahwa tanggung jawab perusahaan tidak lagi pada single bottom line, yang hanya memperhatikan kondisi keuangan saja, tetapi juga memasukkan masalah sosial dan lingkungan atau triple bottom lines, yaitu profit, people and planet (3P). Profit artinya perusahaan harus tetap berorientasi pada pencapaian keuntungan ekonomi yang memungkinkan terus beroperasi dan berkembang. People artinya perusahaan harus memiliki kepedulian terhadap kesejahteraan manusia, seperti kepedulian perusahaan pada pendidikan, kesehatan dan capacity building masyarakat lokal. Sedangkan planet artinya setiap perusahaan harus peduli terhadap masalah lingkungan hidup.

Menyadari akan pentingnya triple bottom line, pada akhirnya tanggung jawab terhadap masalah sosial dan lingkungan ini diwujudkan oleh perusahaan dalam bentuk kegiatan-kegiatan Corporate Social Responsibility (CSR). Corporate Social Responsibility merupakan komitmen perusahaan 
untuk memberikan kontribusi jangka panjang terhadap satu isu tertentu di masyarakat atau lingkungan untuk dapat menciptakan lingkungan yang lebih baik. Konsep CSR mengemuka sejak sekitar tahun 1990-an, yang berawal dari konsep kekayaan di Amerika Serikat. Salah satu tokoh yang melahirkan ide tentang CSR adalah Andrew Carnegie seorang konglomerat pendiri perusahaan U.S. Steel, yang pada tahun 1889 menerbitkan buku yang berjudul The Gospel of Wealth. Secara garis besar buku ini mengemukakan pernyataan klasik mengenai tanggung jawab sosial perusahaan. Pemikiran Carnegie didasarkan pada dua prinsip, yaitu prinsip amal dan prinsip mengurus harta orang lain (Oktarizal, Triyuwono, \& Achsin, 2014).

Pelaksanaan CSR di Indonesia sendiri sudah diatur dalam UU No. 40 Tahun 2007 tentang Perseroan Terbatas. Dalam undang-undang ini diatur mengenai tanggung jawab sosial dan lingkungan yang bertujuan mewujudkan pembangunan ekonomi berkelanjutan guna meningkatkan kualitas kehidupan dan lingkungan yang bermanfaat bagi perseroan itu sendiri, komunitas setempat, dan masyarakat umumnya.

Kegiatan CSR yang dilakukan oleh perusahaan sangat beraneka ragam, yang dikelompokkan menjadi beberapa isu sosial, antara lain isu bidang pendidikan, kesehatan, lingkungan dan pelestarian alam, dan atau berbagai bantuan permodalan bagi masyarakat (Kotler \& Lee, 2005). Dari beberapa isu tersebut, isu yang paling dilirik saat ini adalah pendidikan. Karena seiring dengan derasnya tantangan global, tantangan dunia pendidikan menjadi semakin besar.

Berdasarkan data Kementerian Pendidikan dan Kebudayaan (Kemendikbud) tahun 2010, di Indonesia terdapat lebih dari 1,8 juta anak setiap tahun yang tidak dapat melanjutkan pendidikan. Hal ini disebabkan oleh tiga faktor, yaitu faktor ekonomi, anak - anak yang terpaksa bekerja untuk mendukung ekonomi keluarga; dan pernikahan di usia dini. Dikatakan pula bahwa 75 persen sekolah di Indonesia tidak memenuhi standar layanan minimal pendidikan. Dari sekitar 40.000 sekolah pada tahun 2012, diketahui bahwa isi, proses, fasilitas, dan pengelolaan sebagian besar sekolahnya masih belum sesuai dengan standar pendidikan yang baik seperti diamanatkan Undang-Undang. Ini semua karena kurangnya keseriusan dalam mempersiapkan layanan pendidikan yang baik, serta masih kurangnya motivasi dari para siswa dalam mendapatkan pendidikan.

Dalam laporan terbaru Program Pembangunan PBB tahun 2013, Indonesia menempati posisi 121 dari 185 negara dalam Indeks Pembangunan Manusia (IPM) dengan angka 0,629. Dengan angka itu Indonesia tertinggal dari dua negara tetangga ASEAN yaitu Malaysia (peringkat 64) dan Singapura (peringkat 18). Sedangkan data dalam Education For All (EFA) Global Monitoring Report 2011: The Hidden Crisis, Armed Conflict and Education yang dikeluarkan Organisasi Pendidikan, Ilmu Pengetahuan, dan Kebudayaan Perserikatan Bangsa-Bangsa (UNESCO) yang diluncurkan di New York pada awal tahun 2011, Indeks Pembangunan Pendidikan atau Education Development Index (EDI) berdasarkan data tahun 2008 adalah 0,934. Nilai itu menempatkan Indonesia di posisi ke-69 dari 127 
negara di dunia (Disdikpora, 2014). Di dalam negeri sendiri, selama satu dekade ini perkembangan pendidikan di Indonesia dalam posisi stagnan, sementara negara lain sedang mempersiapkan pertarungan dunia (Kemendikbud, 2012). Untuk itu diperlukan keseriusan dalam memperbaiki kondisi tersebut, serta dukungan dari berbagai pihak.

Fakta-fakta di atas membuktikan bahwa pendidikan Indonesia belum bisa disebut baik. Hal ini tentunya menjadi tugas bagi seluruh elemen untuk turut serta meningkatkan mutu pendidikan di Indonesia. Sebab peran serta masyarakat atau pihak lain dalam peningkatan mutu pendidikan telah disinggung dalam UU RI No. 21 Tahun 2003 tentang Sistem Pendidikan Nasional pada pasal 54. Peran serta tersebut meliputi peran serta organisasi profesi, pengusaha, dan organisasi kemasyarakatan dalam penyelenggaraan dan pengendalian mutu layanan pendidikan.

Peraturan tersebut tentunya berlaku pula pada perusahaan sebagai salah satu organisasi profesi yang juga memiliki tanggung jawab sosial. Dalam hal ini, perusahaan mengalokasikan dana CSR pada beberapa sektor yang mana besarnya alokasi CSR pada tiap isu/sektor ditentukan oleh kebijakan masing-masing perusahaan. Namun, terdapat beberapa fakta menarik mengenai pengalokasian dana CSR pada beberapa perusahaan di Indonesia dalam 4 tahun terakhir.

Pada tahun 2011, Executive Vice President Distribution Network I Group Bank Mandiri; Heri Gunardimenuturkan bahwa perseroannya telah mengalokasikan dana CSR senilai Rp9,8 miliar dan sekitar 60\% dialokasikan untuk sektor pendidikan. Sementara sisanya, digelontorkan pada sektor kesehatan, sosial, dan lainnya. Pada tahun 2012, PT Bank Rakyat Indonesia Tbk Kantor Wilayah Bandung telah menyalurkan dana Corporate Social Responsibility (CSR) sebesar Rp 8.960.942.934. Dari dana tersebut, sekitar 87\% dialokasikan pada sektor pendidikan yaitu Rp 7.816.978.284 (Rakyat, 2012). Pada tahun 2013, Environment Social \& Responsibility Division Head Astra Internasional; Riza Deliansyah menuturkan bahwa di tahun 2013 dana CSR yang dikucurkan Astra Internasional sampai Rp500 miliar dan sebagian besar akan diarahkan untuk program pendidikan. Tahun 2014, Kepala Divisi Tanggung Jawab Sosial dan Lingkungan PT Perusahaan Gas Negara (PGN); Enik Indriastuti menuturkan bahwa dana CSR PT PGN sebesar 30-40\% dialokasikan untuk dunia pendidikan di Jawa Timur dari total dana CSR sebesar Rp 160 miliar pada tahun 2014.

Fenomena ini menjadi menarik untuk dianalisis lebih lanjut. Pada 4 tahun terakhir, nyatanya alokasi dana CSR pada perusahaan maupun perbankan sangatlah besar untuk sektor pendidikan. Dari fakta tersebut dapat diasumsikan bahwa fenomena ini merupakan salah satu cara perusahaan berkontribusi atas berbagai masalah pendidikan yang dihadapi Indonesia setiap tahunnya.

Pada awalnya praktik pelaksanaan serta pelaporan CSR di Indonesia didominasi oleh perusahaan - perusahaan yang go public dan bergerak dalam sektor pertambangan atau manufaktur, hingga kemudian diikuti oleh perusahaan sektor perbankan. Perbankan terdiri dari 2 jenis, yaitu perbankan 
umum (konvesional) dan perbankan syariah. Perbankan syariah yang kini perkembangannya sedang melaju pesat di Indonesia pun termasuk ke dalam kategori perusahaan yang diatur oleh UU di atas. Bank syariah selain memiliki kepentingan bisnis, juga mengusung sebuah tanggung jawab etis yang harus dijalankan, terutama yang terkait dengan fungsi sosialnya. Sebagaimana dijelaskan pada UU No 21/2008 tentang Perbankan Syariah. Dalam landasan falsafahnya dinyatakan bahwa perbankan syariah ditujukan untuk mencari keridhaan Allah SWT, dan untuk memperoleh kebajikan di dunia dan akhirat. Landasan tersebut menjadi nilai lebih yang tidak dimiliki oleh bank konvensional. Namun pada saat yang bersamaan dikhawatirkan hal tersebut juga bisa menjadi kelemahan yang mencolok manakala tidak diimplementasikan dengan sepenuhnya.

CSR mempunyai makna yang berbeda bagi orang yang berbeda. Bagi sebagian orang, CSR adalah prakarsa untuk menaikkan reputasi. Bagi yang lain, CSR adalah suatu tindakan kedermawanan yang mulia. Perbedaan persepsi atau makna tentang CSR sangat tergantung dari sejauh mana orang menafsirkan itu untuk memahami CSR. Masalah persepsi tidak hanya terletak pada nilai nilai yang dianut oleh indvidu yang berdiri sendiri atau setiap aktor dalam suatu komunitas/organisasi (Oktarizal, Triyuwono, \& Achsin, 2014).

Hal ini seakan mendukung pernyataan yang telah disinggung dalam paragraf sebelumnya atas kekhawatiran dilaksanakannya program CSR di bank-bank syariah. Kekhawatiran ini bukan tanpa alasan jika melihat pada realita bank syariah saat ini. Realita yang dimaksud adalah kondisi-kondisi riil dimana bank syariah; (1) Telah mereduksi makna fungsi sosial menjadi peyaluran dana sosial (Zakat, Infak Sadaqah/ ZIS); (2) Lebih mementingkan kepentingan jangka pendek dalam bentuk keuntungan materi, tidak ubahnya bank konvensional; (3) Lemah dalam aspek sumber daya manusia, dimana SDM yang tersedia kurang atau bahkan tidak mengenal hukum Islam, serta; (4) Minimnya upaya sosialisasi atau pendidikan terhadap masyarakat. Hal ini membawa akibat serius terhadap keberlangsungan masa depan bank syariah itu sendiri.

Kekhawatiran tersebut dibuktikan oleh penelitian yang telah dilakukan Naraduhita dan Sawarjuwono (2012) mengenai "Upaya Memahami Alasan Dibalik Pengungkapan CSR Bidang Pendidikan". Penelitian ini menyimpulkan bahwa dari 10 sample perusahaan (termasuk perbankan) yang dianalasis menggunakan analysis content, 5 diantaranya terindikasi menyelipkan kepentingan bisnis di dalam program-program CSR mereka. Artinya, 5 perusahaan yang juga terdiri dari perbankan tersebut tidak melaksanakan tanggung jawab sosial secara penuh, melainkan menyelipkan kepentingan lain di dalamnya. Padahal, tanggung jawab sosial yang dijalankan dengan baik oleh perusahaan secara langsung maupun tidak langsung memiliki dampak positif terhadap pengembangan perusahaan itu sendiri. Mengenai hal ini telah dijelaskan dalam surat Al Insyirah ayat 7 yang artinya: "Maka apabila kamu telah selesai suatu urusan, tetaplah bekerja keras untuk urusan yang lain". Dari ayat tersebut dapat kita simpulkan bahwa janganlah menggabungkan satu urusan dengan urusan lainnya. 
Berdasarkan uraian di atas, maka timbul pertanyaan apakah fenomena yang telah dibuktikan oleh Naraduhita dan Sawarjuwono pada tahun 2012 tersebut juga terjadi pada Bank Umum Syariah di Indonesia? Apakah Bank Umum Syariah benar-benar mengungkapkannya karena kesadaran dan kepedulian terhadap masalah sosial dan lingkungan, khususnya pendidikan, atau adanya kepentingan bisnis dibaliknya? Seperti misalnya sekedar upaya untuk "mempromosikan" perusahaan dan produknya, pencitraan, atau hanya untuk mematuhi semua peraturan dan perundang-undangan yang ada.

Pemikiran demikian layak diajukan, karena penyajian kegiatan CSR masih bersifat voluntarily (Wibisono, 2007). Sebagaimana disebutkan secara implisit dalam PSAK No 1 (Revisi 2013) paragraf ke-16. Bank Indonesia melalui Surat Edaran BI No. 7/56/DPbs tentang laporan tahunan juga telah menjelaskan poin-poin yang perlu untuk diungkapkan. Di dalamnya juga dijelaskan bahwa pengungkapan informasi dalam laporan tahunan perusahaan dapat diklasifikasikan menjadi dua, yaitu pengungkapan wajib (mandatory disclosure) merupakan pengungkapan minimum yang disyaratkan oleh standar akuntansi yang berlaku untuk diungkapkan dan lembaga yang berwenang IAI (Ikatan Akuntan Indonesia), dan pengungkapan sukarela (voluntary dislcosure) merupakan pilihan bebas manajemen perusahaan untuk memberikan informasi akuntansi dan informasi lainnya yang dipandang relevan untuk keputusan para pemakai laporan keuangan (Ali, 2015). Namun walaupun masih bersifat sukarela, telah banyak perusahaan yang melaporkan kegiatan CSR ini baik dalam laporan tahunan maupun dalam laporan keberlanjutan. Sifat penyajian laporan keuangan yang bersifat sukarela ini yang kemudian mendasari perlunya evaluasi terhadap laporan CSR yang diungkapkan oleh perusahaan. Karena motivasi perusahaan mengungkapkan CSR dalam laporan tahunan bisa jadi mempunyai latar belakang yang berbeda.

Terutama dalam konteks Bank Umum Syariah, CSR yang dijalankan seharusnya tidak hanya berlandaskan pada pedoman umum saja, tetapi juga harus sesuai dengan prinsip-prinsip dasar Islam. Hal ini sebagaimana disebutkan dalam Al Qur'an sebagai pedoman dasar ummat Islam. Diantaranya yaitu dalam surat $\mathrm{Al}$ Maidah ayat 32 tentang menjaga lingkungan dan melestarikannya, dalam surat Al Hasyr ayat 7 tentang upaya untuk menghapus kemiskinan, dalam surat Al Maidah ayat 103 tentang mndahulukan sesuatu yang bermoral bersih daripada sesuatu yang secara moral kotor walaupun mendatangkan keuntungan yang lebih besar, dan dalam surat Al Anfal ayat 27 tentang jujur dan amanah.

Namun sejauh ini, kebanyakan penelitian yang membahas tentang CSR hanya menganalisis luas pengungkapan CSR pada laporan keuangan perusahaan. Padahal lebih jauh daripada itu, perlu adanya evaluasi dan pemahaman akan makna dibalik pengungkapan CSR di perusahaan itu sendiri. Hal itu yang kemudian mendasari munculnya penelitian ini, sebagai evaluasi terhadap laporan CSR yang diungkapkan oleh Bank Umum Syariah (BUS) di Indonesia khususnya dalam bidang pendidikan. 


\section{LANDASAN TEORI}

\subsection{Teori Ekonomi Politik, Teori Stakeholders, dan Teori Legitmasi}

Menurut Farook (2011) yang menyimpulkan dari berbagai ahli bahwa diantara banyak literatur yang mendasari konsep perngungkapan CSR, teoriteori berbasis sistem atau system-oriented theories dianggap paling mewakili. System-oriented theories yang dimaksud diantaranya sebagai berikut:

1. Teori Ekonomi Politik (Politik Economy Theory)

Roberts (1992) dan Williams (1999) seperti yang dikutip oleh Farook (2011)menyebutkan bahwa konteks politik dan sosial dianggap merupakan faktor penting dalam penentuan keputusan untuk melakukan pengungkapan informasi CSR informasi CSR perusahaan. Konsep teori ekonomi politik ini diterjemahkan sebagai kerangka ekonomi, sosial, dan politik dimana kehidupan manusia berlangsung (Gray, 1996). Menurut Guthrie \& Parker (1990) dalam Cunningham yang dikutip oleh Purwitasari (2011):

"Perspektif ekonomi politik memandang laporan akuntansi sebagai dokumen sosial, politik, dan ekonomi. Dokumendokumen ini berfungsi sebagai alat untuk membangun, mempertahankan, dan melegitimasi pengaturan ekonomi dan politik, lembaga, dan tema-tema ideologis yang berkontribusi untuk kepentingan pribadi korporasi. Pengungkapan memiliki kapasitas untuk mengirimkan sosial, politik, dan ekonomi pengertian untuk satu set pluralistik penerima laporan"

Oleh karena itu, political economy theory dikatakan dapat meluaskan level analisa seorang peneliti karena mempertimbangkan isu sosio-politik yang lebih luas yang akan berimplikasi pada bagaimana perusahaan beroperasi dan informasi apa saja yang terpilih untu diungkapkan (Deegan, 2003 dalam Purwitasari, 2011).

2. Teori Legitimasi (Legitimacy Theory)

Menurut Belal (2008) seperti yang dikutip oleh Purwitasari (2011) berpendapat bahwa legitimacy theory merupakan salah satu bentuk aplikasi dari political economy theory dari sudut pandang borjuis, karena teori ini berhubungan dengan negosiasi yang dilakukan antara organisasi dengan masyarakat (stakeholder) di lingkungan yang bersifat pluralistik. Legitimacy theory berasal dari konsep legitimasi organisasi (Guthrie,2007). Konsep legitimasi organisasi didefinisikan oleh Dowling \& Pfeffer (1975) dalam Guthrie (2007) sebagai”

“... kondisi atau status yang terjadi ketika sistem nilai suatu entitas yang digunakan sesuai dengan sistem nilai sosial yang lebih luas yang merupakan bagian entitas. Ketika disparitas, aktual atau potensial, ada antara kedua sistem nilai, ada ancaman bagi entitas legitimasi."

Berdasarkan definisi tersebut, legitimacy theory berpandangan bahwa terdapat "kontrak sosial" antara perusahaan dengan lingkungan tempat 
perusahaan beroperasi (Deegan, 2002). Menurut Deegan (2002) kontrak sosial digunakan untuk menjelaskan tentang anggapan dari masyarakat tentang bagaimana seharusnya sebuah perusahaan beroperasi. Terutama apabila aktivitas perusahaan tersebut dianggap melanggar kontrak sosial oleh mayarakat sehingga menganca kelangsungan operasional perusahaan itu sendiri (Deegan, 2002).

Menurut teori ini, perusahaan akan melakukan aktivitas CSR dikarenakan adanya tekanan sosial, politik, dan ekonomi dari luar perusahaan. Sehingga perusahaan akan menyeimbangkan tuntutan tersebut dengan melakukan apa yang diinginkan oleh masyarakat dan apa yang diharuskan oleh peraturan (Deegan, 2002).

3. Teori Stakeholder (Stakeholder Theory)

Aktivitas CSR yang dilakukan oleh perusahaan menurut teori ini didasarkan pada tujuan untuk mengakomodasi keringanan dan kebutuhan pemangku kepentingan (stakeholder) sehingga perusahaan dapat beraktivitas dengan baik dengan seluruh dukungan stakeholder tersebut (Clarkson, 1995 dalam Fitria 2010).

Grey (1995) menegaskan bahwa dalam stakeholder theory:

"the corporation's continued existence requires the support of the stakeholders and their approval must be sought and the activities of the corporation adjusted to gain that approval. The more powerful the stahkeholders, the more the company must adapt. Social disclosures is thus seen as part of the dialogue between the company and its stakeholder."

Sehingga aktivitas CSR menurut teori ini dilakukan untuk mengakomodasi keinginan dan kebutuhan stakeholder sehingga perusahaan dapat beraktivitas dengan baik dengan seluruh dukungan stakeholder tersebut (Clarkson, 1995 dalam Fitria, 2010)

Menurut Ulman (1985) dalam Purwitasari (2011) berpendapat bahwa kekuatan dari stakeholder berantung pada strategi yang digunakan oleh perusahaan. Menurut Ulman (1985), bentuk strategi yang digunakan oleh perusahaan adalah "the mode of response of an organization's key decision makers towards social demands". Sehingga berdasarkan teori legitimasi ini keputusan menyangkut aktivitas maupun pengungkapan CSR dilakukan atas dasar perpektif manajer (Gray, 1995).

\subsection{Pengungkapan}

Pengungkapan (disclosure) adalah informasi yang diberikan oleh perusahaan kepada pihak-pihak yang berkepentingan mengenai keadaan perusahaan. Didalam pengungkapan semua informasi harus diungkapkan termasuk informasi kuantitatif (seperti komponen persediaan dalam nilai mata uang), dan komponen kualitatif (seperti tuntutan hukum), bahkan menurut SEC setiap kejadian yang terjadi dengan tiba-tiba yang dapat mempengaruhi posisi keuangan harus diungkapkan secara khusus (GAAP,1998:42) 
Sedangkan menurut Siegel dan Shim (1994) pengungkapan adalah pengungkapan atas informasi yang diberikan sebagai lampiran pada laporan keuangan sebagai catatan kaki atau tambahan. Informasi ini menyediakan penjelasan yang lebih lengkap mengenai posisi keuangan, hasil operasi, dan kebijakan perusahaan. Informasi penjelasan mengenai kesehatan keuangan dapat juga diberikan dalam laporan pemeriksaan. Semua materi harus disingkapkan termasuk informasi kuantitatif maupun kualitatif yang sangat membantu pengguna laporan.

\subsection{Pengungkapan Tanggung Jawab Sosial Perusahaan}

Jenis pengungkapan yang digunakan perusahaan untuk memberikan informasi kepada stakeholders terbagi menjadi 2 jenis, yaitu Pengungkapan Wajib (Mandatory Disclosure) dan Pengungkapan Sukarela

Pelaporan pengungkapan sosial dalam laporan tahunan merupakan voluntary disclosure, artinya pengungkapan ini bersifat sukarela dan belum diatur secara tegas dalam PSAK. Pada PSAK No.1 (Revisi 2009) paragraf 12 dinyatakan bahwa:

"Entitas dapat pula menyajikan, terpisah dari laporan keuangan, laporan mengenai lingkungan hidup dan laporan nilai tambah (value added statement), khususnya bagi industri dimana faktor lingkungan hidup memegang peranan penting dan bagi industri yang menganggap karyawan sebagai kelompok pengguna laporan yang memegang peranan penting. Laporan tambahan tersebut di luar ruang lingkup Standar Akuntansi Keuangan."

Namun dengan kondisi saat ini, stakeholder mulai menganggap pengungkapan tanggung jawab sosial itu menjadi salah satu yang penting. Dalam Keputusan Ketua Bapepam No. Kep-38/PM/1996, di Peraturan Nomor VIII.G.2 tetang Laporan Tahunan, juga diatur tentang uraian mengenai keikutsertaan perusahaan dalam kegiatan pelayanan masyarakat, program kemasyarakatan, amal, atau acara sosial lainnya. Peraturan ini menunjukan bahwa laporan mengenai tanggung jawab sosial perusahaan terhadap masyarakat perlu untuk dicantumkan.

Dalam konteks Islam, masyarakat mempunyai hak untuk mengetahui berbagai informasi mengenai aktivitas organisasi atau perusahaan, khususnya yang berhubungan dengan masyarakat luas. Hal ini dilakukan untuk melihat apakah perusahaan telah melakukan kegiatannya sesuai syariah dan mencapai tujuan yang sudah ditetapkan (Baydoun \& Wilett, 2000).

\subsection{Tanggung Jawab Sosial Perusahaan (Corporate SocialResponsibility)}

Corporate Social Responsibility mengandung kata "responsibility" yang berasal dari"response" (tindakan untuk merespon suatu masalah atau isu) dan "ability" (kemampuan). Maknanya, responsibility merupakan tindakan yang bersifat sukarela, karena respon yang dilakukan disesuaikan dengan ability yang bersangkutan. Sehingga Corporate Social Responsibility (CSR) atau Tanggung Jawab Sosial Perusahaan, merupakan mekanisme bagi suatu 
organisasi untuk secara sukarela mengintegrasikan perhatian terhadap lingkungan dan sosial ke dalam operasi dan interaksinya dengan stakeholders, yang melebihi tanggungjawab organisasi dibidang hukum (Darwin, 2004).

Pengertian pengungkapan juga dijelaskan oleh Fleishman (2007) dalam survei yang berjudul "Rethingking Corporate Social Responsibility". Fleishman menggambarkan arti dari CSR seperti terlihat dalam grafik berikut:

Grafik 2. Arti Tanggung Jawab Sosial Perusahaan

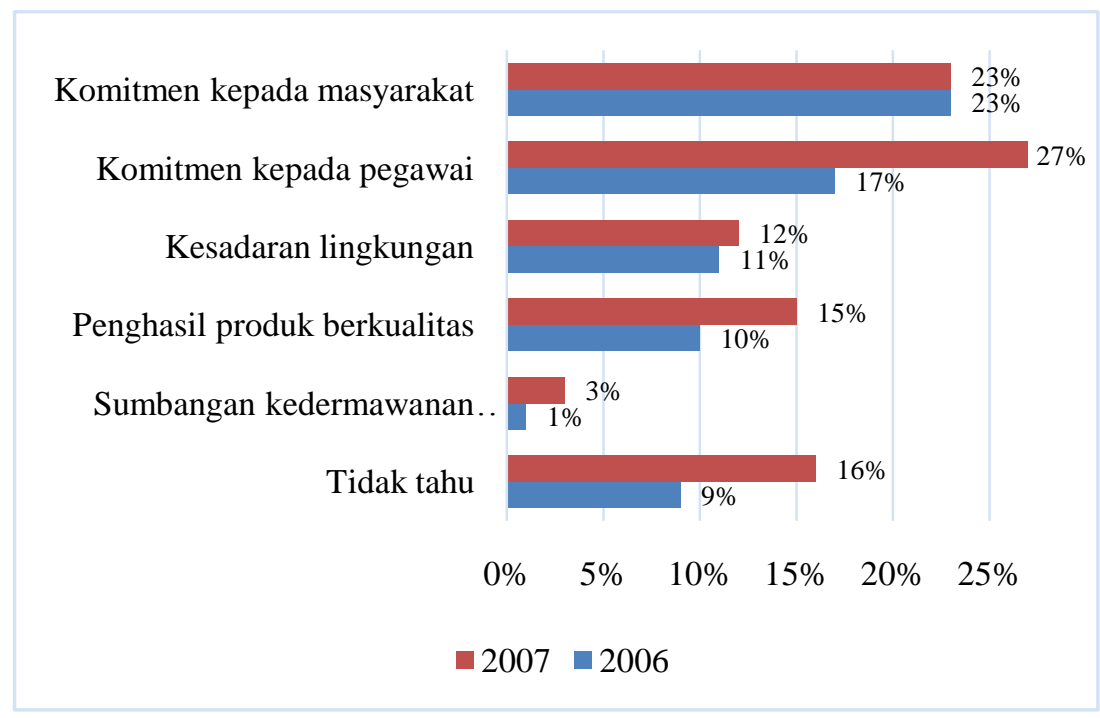

Sumber: (Rahman, 2009)

Dari grafik tersebut, $23 \%$ responden selama dua tahun memaknai CSR sebagai sebuah komitmen kepada masyarakat. Pada 2007, terjadi peningkatan sebanyak $10 \%$ pada persepsi responden yang memaknai CSR sebagain komitmen CSR sebagai komitmen kepada pegawai. Kesadaran lingkungan dalam kegiatan CSR juga menjadi perhatian responden, hal itu diindikaskan dengan adanya peningkatan sebesar $1 \%$ pada tahun berikutnya. Di samping itu, CSR juga dimaknai sebagai usaha menghasilkan produk yang berkualitas dan aktivitas kemanusiaan. Masing-masing di persepsikan oleh 15\% dan 3\% responden pada 2007. Persentase ini meningkat dibandingkan tahun sebelumnya sebesar $5 \%$ dan $2 \%$.

\subsection{CSR Dalam Perspektif Islam}

CSR dalam perspektif Islam merupakan konsekuensi inhern antara ajaran Islam itu sendiri. Tujuan dari syariat Islam (maqashid al syariah)adalah maslahah, sehingga bisnis adalah upaya untuk menciptakan mashalah, bukan sekedar mencari keuntungan. Menurut Naqvy (1996), kegiatan ekonomi dan 
bisnis dalam Islam dilandasi oleh aksioma tauhid, keseimbangan, kebebasan, dan pertanggungjawaban. Aksioma-aksioma ini harus dimplementasikan dalam seluruh aspek kegiatan ekonomi dan bisnis. Aksioma keseimbangan dan pertanggungjawaban, misalnya, akan membawa implikasi pada keseimbangan dan pertanggungjawaban antara jiwa dan raga, Antara person dan keluarga, Antara individu dan social, Antara suatu masyarakat dengan masyarakat lainnya (Beekun, 1997).

\section{METODE PENELITIAN}

Penelitian ini menggunakan metode deskriptif kualitatif mengenai latar belakang atau motivasi pengungkapan program CSR dalam Laporan Tahunan Bank Umum Syariah (BUS) di Indonesia.

Populasi dalam penelitian ini merupakan seluruh Bank Umum Syariah (BUS) di Indonesia yang tercatat di statistik perbankan syariah yang diterbitkan oleh BI (Bank Indonesia) yang per 1 Januari 2014 berpindah kekuasaan kepada OJK (Otoritas Jasa Keuangan) periode 2013 dan 2014.

Sembilan BUS yang menjadi sampel penelitian, yaitu Bank Muamalat Indonesia (BMI), Bank Syariah Mandiri (BSM), Bank Mega Syariah (BMS), Bank Rakyat Indonesia Syariah (BRIS), Bank Syariah Bukopin (BSB), Bank Panin Syariah (BPS), BCA Syariah (BCAS), BNI Syariah (BNIS), dan Maybank Syariah (MBS).

Teknik yang digunakan dalam penelitian ini menggunakan teknik content analysis terhadap Laporan Tahunan perusahaan. Content Analysis atau analisis isi adalah pemrosesan dalam data ilmiah dengan tujuan memberikan pengetahuan, membuka wawasan baru dan menyajikan fakta (Kripendoff, 1991).

\section{PEMBAHASAN}

Sebelum mengetahui lebih jauh mengenai pengungkapan CSR bidang pendidikan, tentu perlu diketahui bagaimana luas pengungkapan CSR baik secara umum maupun khusus (CSR bidang pendidikan) pada masing-masing BUS yang terpilih menjadi sampel. Perhitungan ini dilakukan karena terdapat perbedaan pada tiap BUS dalam mengungkapkan laporan CSR, mengingat tidak adanya peraturan ataupun standar pengungkapan laporan CSR dalam Laporan Tahunan Bank Umum Syariah.

Dari sembilan sampel BUS yang terpilih, maka hasil perhitungan luas pengungkapan CSRnya adalah sebagai berikut:

\begin{tabular}{|c|c|c|c|c|c|}
\hline \multirow{3}{*}{ No } & \multirow{3}{*}{ Bank Umum Syariah } & \multicolumn{4}{|c|}{ Jumlah kalimat/ frase mengenai CSR } \\
\hline & & \multicolumn{2}{|c|}{2013} & \multicolumn{2}{|c|}{2014} \\
\hline & & Umum & Pendidikan & Umum & Pendidikan \\
\hline 1 & $\begin{array}{l}\text { Bank } \\
\text { Indonesia }\end{array}$ & 132 & 13 & 151 & 19 \\
\hline 2 & Bank Syariah Mandiri & 194 & 7 & 129 & 10 \\
\hline 3 & Bank Mega Syariah & 25 & 4 & 12 & 6 \\
\hline
\end{tabular}




\begin{tabular}{clcccc}
\hline 4 & BRI Syariah & 24 & 5 & 29 & 4 \\
\hline 5 & Bank Syariah Bukopin & 54 & 0 & 74 & 18 \\
\hline 6 & Bank Panin Syariah & 10 & 5 & 21 & 14 \\
\hline 7 & BCA Syariah & 9 & 0 & 15 & 1 \\
\hline 8 & BNI Syariah & 119 & 12 & 136 & 8 \\
\hline 9 & Maybank Syariah & 15 & 10 & 21 & 6 \\
\hline
\end{tabular}

Tabel 1. Hasil Perhitungan Luas Pengungkapan CSR

Sumber: Data diolah, 2016

Dari data diatas, terlihat sangat jelas bahwa memang tiap BUS memiliki luas pengungkapan yang berbeda baik pengungkapan secara keseluruhan maupun pengungkapan yang membahas mengenai pendidikan. Pada tahun 2013 saja, rentang jumlah kalimat/ frase mengenai CSR yang diungkapkan dalam Laporan Tahunan masing- masing BUS cukup jauh yaitu berkisar pada 9-194 kalimat/ frase, dan yang membahas mengenai pendidikan berkisar pada 0-13 kalimat/ frase. Sementara pada tahun 2014 kalimat/ frase mengenai CSR yang diungkapkan dalam Laporan Tahunan masing- masing BUS berkisar pada 10-151 kalimat/ frase, dan yang membahas mengenai pendidikan berkisar pada 1-19 kalimat/ frase.

Pada tahun 2013, sebanyak 194 kalimat/ frase mengenai CSR diungkapkan oleh Bank Muamalat Indonesia dalam Laporan Tahunannya. Jumlah tersebut merupakan yang tertinggi diantara delapan BUS lainnya. Artinya di tahun tersebut Bank Muamalat Indonesia menjadi bank yang paling luas dalam hal pengungkapan CSR secara keseluruhan, meskipun dalam luas pengungkapan CSR bidang pendidikan jumah kalimat/ frasenya masih lebih sedikit dibanding kalimat/ frase mengenai CSR bidang pendidikan yang diungkapkan oleh Bank Muamalat Indonesia, BNI Syariah, dan Maybank Syariah. Yang mana tiga bank tersebut menempati urutan tiga BUS yang mengungkapkan kalimat/ frase terbanyak mengenai CSR bidang pendidikan. Luasnya pengungkapan pada bank yang sudah disebutkan sebelumnya berbeda halnya dengan BCA Syariah yang hanya mengungkapkan sebanyak 9 kalimat/ frase mengenai CSR dalam Laporan Tahunannya, dan diketahui dari 9 kalimat/ frase tersebut tidak ada satupun yang membahas mengenai CSR pendidikan. Hal ini terjadi mungkin karena pada tahun 2013, BCA Syariah memang tidak menjadikan bidang pendidikan sebagai bagian dari pelaksanaan tanggung jawab sosial perusahaan. Selain BCA Syariah, Bank Syariah Bukopin juga sama sekali tidak mengungkapkan pembahasan mengenai CSR bidang pendidikan pada tahun tersebut.

Lalu pada tahun 2014, BUS yang paling banyak mengungkapkan kalimat/ frase mengenai CSR baik dalam bidang pendidikan maupun secara keseluruhan masih sama seperti tahun sebelumnya yaitu Bank Muamalat Indonesia -sebanyak 151 kalimat/ frase, yang mana 19 kalimat/ frase diantaranya membahas mengenai CSR bidang pendidikan. Hal ini menandakan bahwa Bank Muamalat Indonesia konsisten dalam hal luas pengungkapan CSR pada Laporan Tahunannya. Kemudian seperti tahun sebelumnya pula, BUS yang paling sedikit mengungkapkan kalimat/ frase 
mengenai CSR secara umum maupun bidang pendidikan dalam Laporan Tahunannya yaitu BCA Syariah. Pada tahun 2014, BCA Syariah mengungkapkan 21 kalimat/ frase mengenai CSR dan hanya 1 kalimat/ frase diantaranya yang membahas mengenai pendidikan.

Luas pengungkapan CSR baik dalam bidang pendidikan maupun secara keseluruhan yang sudah dijelaskan tersebut memang tidak dapat dijadikan patokan dalam menentukan sudah baik atau belumnya pengungkapan yang dilakukan oleh masing- masing BUS. Perlu adanya peninjauan lebih lanjut mengenai makna pengungkapan dari kalimat/ frase tersebut. Jumlah kalimat/ frase yang banyak, belum tentu menandakan bahwa BUS tersebut sudah baik dalam hal pengungkapan laporan CSR. Begitupun sebaliknya, kalimat/ frase yang jumlahnya sedikit belum tentu menandakan bahwa BUS tersebut buruk dalam hal pengungkapan laporan CSR.

Perihal bidang pendidikan, kita ketahui bahwa peran perusahaan sangatlah dinanti oleh masyarakat untuk membantu membenahi perkembangan pendidikan saat ini. Sehingga pengungkapan CSR bidang pendidikan dalam Laporan Tahunannya sangatlah perlu untuk diperhatikan. Maka dari itu, pembahasan selanjutnya adalah mengenai perhitungan kalimat/ frase pada laporan CSR khususnya bidang pendidikan yang mengacu kepada tata cara perhitungan unit referensial. Yaitu pengklasifikasian kalimat/ frase berdasarkan kecenderungannya dalam membahas suatu isu tertentu.

\subsection{Hasil Perhitungan Unit Analisis Referensial}

Pada bagian ini, perhitungan menggunakan unit analisis referensial (selanjutnya disingkat UR) diaplikasikan ke dalam Laporan Tahunan Bank Umum Syariah yang terpilih menjadi sampel. Setelah kalimat/ frase dalam Laporan CSR bidang pendidikan masing- masing BUS diklasifikasikan dan dihitung, maka hasilnya adalah sebagai berikut:

Tabel 2.Hasil Rekapitulasi Perhitungan UR pada BUS tahun 2013

\begin{tabular}{|c|c|c|c|c|c|c|c|c|c|c|c|}
\hline \multirow{2}{*}{$\mathrm{N}$} & \multirow{2}{*}{$\begin{array}{c}\text { Katego } \\
\text { ri }\end{array}$} & \multicolumn{9}{|c|}{ Jumlah Kalimat/ Frase } & \multirow{2}{*}{$\begin{array}{c}\text { Rata- } \\
\text { rata }\end{array}$} \\
\hline & & BMI & BSM & $\begin{array}{c}\text { BM } \\
\text { S }\end{array}$ & $\begin{array}{c}\text { BRI } \\
\text { S }\end{array}$ & $\begin{array}{c}\text { BS } \\
\text { B }\end{array}$ & $\begin{array}{c}\text { BP } \\
\text { S }\end{array}$ & $\begin{array}{l}\text { BC } \\
\text { AS }\end{array}$ & $\begin{array}{c}\text { BNI } \\
\text { S }\end{array}$ & $\begin{array}{c}\mathrm{MB} \\
\mathrm{S}\end{array}$ & \\
\hline 1 & $\begin{array}{l}\text { CSR } \\
\text { Pendidi } \\
\text { kan }\end{array}$ & $\begin{array}{c}8 \\
(61,54 \\
\%) \\
\end{array}$ & $\begin{array}{c}5 \\
(71,43 \\
\%) \\
\end{array}$ & $\begin{array}{c}3 \\
(75 \\
\%) \\
\end{array}$ & $\begin{array}{c}1 \\
(20 \\
\%) \\
\end{array}$ & $\begin{array}{l}- \\
(0 \\
\%) \\
\end{array}$ & $\begin{array}{c}4 \\
(80 \\
\%) \\
\end{array}$ & $\begin{array}{c}- \\
(0 \% \\
) \\
\end{array}$ & $\begin{array}{c}12 \\
(100 \\
\%) \\
\end{array}$ & $\begin{array}{c}2 \\
(20 \\
\%) \\
\end{array}$ & $\begin{array}{l}47,5 \\
5 \%\end{array}$ \\
\hline 2 & $\begin{array}{l}\text { Bisnis/ } \\
\text { Promos } \\
\text { i }\end{array}$ & $\begin{array}{c}1 \\
(7,69 \\
\%) \\
\end{array}$ & $\begin{array}{c}- \\
(0 \%)\end{array}$ & $\begin{array}{c}- \\
(0 \% \\
)\end{array}$ & $\begin{array}{c}4 \\
(80 \\
\%) \\
\end{array}$ & $\begin{array}{l}- \\
(0 \\
\%)\end{array}$ & $\begin{array}{c}1 \\
(20 \\
\%) \\
\end{array}$ & $\begin{array}{c}- \\
(0 \% \\
)\end{array}$ & $(0 \%)$ & $\begin{array}{c}3 \\
(30 \\
\%)\end{array}$ & $\begin{array}{l}15,2 \\
9 \%\end{array}$ \\
\hline 3 & $\begin{array}{l}\text { CSR } \\
\text { Bidang } \\
\text { lainnya }\end{array}$ & $\begin{array}{c}4 \\
(30,77 \\
\%) \\
\end{array}$ & $\begin{array}{c}2 \\
(28,57 \\
\%)\end{array}$ & $\begin{array}{c}1 \\
(25 \\
\%) \\
\end{array}$ & $\begin{array}{c}- \\
(0 \% \\
)\end{array}$ & $\begin{array}{l}- \\
(0 \\
\%)\end{array}$ & $\begin{array}{c}- \\
(0 \% \\
)\end{array}$ & $\begin{array}{c}- \\
(0 \% \\
)\end{array}$ & $(0 \overline{\%})$ & $\begin{array}{c}5 \\
(50 \\
\%) \\
\end{array}$ & $\begin{array}{l}20,2 \\
4 \%\end{array}$ \\
\hline & $\begin{array}{l}\text { Total } \\
\text { Kalima } \\
\text { t }\end{array}$ & 13 & 7 & 4 & 5 & 0 & 5 & 0 & 12 & 10 & 6,22 \\
\hline
\end{tabular}


Tabel 3. Hasil Rekapitulasi Perhitungan UR pada BUS tahun 2014

\begin{tabular}{|c|c|c|c|c|c|c|c|c|c|c|c|}
\hline \multirow{2}{*}{$\mathrm{N}$} & \multirow{2}{*}{$\begin{array}{c}\text { Katego } \\
\text { ri }\end{array}$} & \multicolumn{9}{|c|}{ Jumlah Kalimat/ Frase } & \multirow{2}{*}{$\begin{array}{c}\text { Rata } \\
- \\
\text { rata }\end{array}$} \\
\hline & & BMI & $\begin{array}{c}\text { BS } \\
\text { M }\end{array}$ & BMS & $\begin{array}{c}\text { BRI } \\
\text { S }\end{array}$ & $\begin{array}{c}\text { BS } \\
\text { B }\end{array}$ & BPS & $\begin{array}{l}\text { BC } \\
\text { AS }\end{array}$ & $\begin{array}{c}\text { BNI } \\
\text { S }\end{array}$ & $\begin{array}{c}\mathrm{MB} \\
\mathrm{S}\end{array}$ & \\
\hline 1 & $\begin{array}{l}\text { CSR } \\
\text { Pendid } \\
\text { ikan } \\
\end{array}$ & $\begin{array}{c}12 \\
(63,1 \\
6 \%) \\
\end{array}$ & $\begin{array}{c}8 \\
(80 \\
\%) \\
\end{array}$ & $\begin{array}{c}2 \\
(13,3 \\
3 \%) \\
\end{array}$ & $\begin{array}{c}3 \\
(75 \\
\%) \\
\end{array}$ & $\begin{array}{c}9 \\
(50 \\
\%) \\
\end{array}$ & $\begin{array}{c}5 \\
(35,7 \\
1 \%) \\
\end{array}$ & $(0 \%)$ & $\begin{array}{c}8 \\
(100 \\
\%) \\
\end{array}$ & $\begin{array}{c}3 \\
(50 \\
\%) \\
\end{array}$ & $\begin{array}{c}51,9 \\
1 \%\end{array}$ \\
\hline 2 & $\begin{array}{l}\text { Bisnis/ } \\
\text { Promo } \\
\text { si } \\
\end{array}$ & $\begin{array}{c}1 \\
(5,26 \\
\%) \\
\end{array}$ & $\begin{array}{c}- \\
(0 \% \\
)\end{array}$ & $\begin{array}{c}1 \\
(16,6 \\
7 \%) \\
\end{array}$ & $\begin{array}{l}1 \\
(25 \\
\%) \\
\end{array}$ & $\begin{array}{c}9 \\
(50 \\
\%) \\
\end{array}$ & $\begin{array}{c}- \\
(0 \%)\end{array}$ & $\begin{array}{c}1 \\
(100 \\
\%) \\
\end{array}$ & $\begin{array}{c}- \\
(0 \%)\end{array}$ & $\begin{array}{c}- \\
(0 \% \\
)\end{array}$ & $\begin{array}{c}21,8 \\
8 \%\end{array}$ \\
\hline 3 & $\begin{array}{l}\text { CSR } \\
\text { Bidang } \\
\text { lainnya }\end{array}$ & $\begin{array}{c}6 \\
(31,5 \\
8 \%) \\
\end{array}$ & $\begin{array}{l}2 \\
(20 \\
\%) \\
\end{array}$ & $\begin{array}{c}3 \\
(50 \%)\end{array}$ & $\begin{array}{c}- \\
(0 \% \\
)\end{array}$ & $\begin{array}{c}- \\
(0 \% \\
)\end{array}$ & $\begin{array}{c}9 \\
(64,2 \\
9 \%)\end{array}$ & $\begin{array}{c}- \\
(0 \%)\end{array}$ & $\begin{array}{c}- \\
(0 \%)\end{array}$ & $\begin{array}{c}3 \\
(50 \\
\%) \\
\end{array}$ & $\begin{array}{c}23,9 \\
8 \%\end{array}$ \\
\hline & $\begin{array}{l}\text { Total } \\
\text { Kalima } \\
\mathrm{t}\end{array}$ & 19 & 10 & 6 & 4 & 18 & 14 & 1 & 8 & 6 & 9,55 \\
\hline
\end{tabular}

Tabel di atas menunjukan klasifikasi kalimat/ frase yang terdapat pada Laporan CSR bidang pendidikan dalam Laporan Tahunan masing- masing BUS yang menjadi sampel. Dari data tersebut, dapat dilihat bahwa klasifikasi kalimat/ frase terbagi menjadi 3 kategori. Yaitu kategori CSR pendidikan, bisnis/ promosi, dan CSR bidang lainnya.

Di tahun 2013, persentase kategori CSR pendidikan berkisar pada angka $20-100 \%$ dengan rata-rata 47,55\%. Persentase tertinggi dimiliki oleh BNI Syariah yang mana pengungkapan kalimat/ frase mengenai CSR bidang pendidikannya mencapai $100 \%$ dari keseluruhan Laporan CSR bidang pendidikan. Artinya, laporan CSR bidang pendidikan BNI Syariah murni mengungkapkan kalimat/ frase yang membahas mengenai CSR pendidikan. Tidak ditemukan kepentingan ataupun tujuan lain seperti pengungkapan kalimat/ frase mengenai bisnis/ promosi atau pun CSR bidang lainnya dalam laporan tersebut. Di samping itu, tentunya terdapat pula BUS yang memiliki persentase terendah dalam hal pengungkapan CSR bidang pendidikan. Posisi tersebut dimiliki oleh BRI Syariah dan Maybank Syariah yang persentasenya yaitu 20\% dari keseluruhan Laporan CSR bidang pendidikan. Artinya, laporan CSR bidang pendidikan BRI Syariah dan Maybank Syariah masih dianggap lemah dalam pengungkapan CSR bidang pendidikannya dan terindikasi memiliki kepentingan atau tujuan lain selain pengungkapan kalimat/ frase mengenai CSR pendidikan dalam pengungkapan laporannya.

Pada kategori bisnis/ promosi, persentasenya berkisar pada angka 0$80 \%$ dengan rata- rata $15,29 \%$. Posisi tertinggi dimiliki oleh BRI Syariah yang mengungkapkan kalimat/ frase mengenai bisnis/ promosi sebesar $80 \%$ dari keseluruhan laporan CSR bidang pendidikan. Tingginya persentase tersebut memunculkan asumsi bahwa kalimat/ frase yang diungkapkan BRI Syariah dalam laporan tersebut memiliki tujuan atau kepentingan lain khususnya dalam hal bisnis/ promosi perusahaan yang seharusnya tidak diungkapkan dalam laporan CSR bidang pendidikan. Asumsi ini didukung oleh besarnya persentase dari pengungkapan kalimat/ frase seharusnya mengenai CSR pendidikan seperti yang sudah dibahas pada paragraf 
sebelumnya, yaitu sebesar 20\% dari keseluruhan laporan CSR bidang pendidikan. Dalam perhitungan kategori ini, persentase terendah dimiliki oleh tiga BUS, yang mana masing- masing dari mereka memiliki persentase sebesar 0\% dalam mengungkapkan kalimat/ frase mengenai bisnis/ promosi. 3 BUS tersebut yaitu Bank Syariah Mandiri, Bank Mega Syariah, dan BNI Syariah. Namun, belum tentu ketiga BUS tersebut terbebas dari asumsi pengungkapan kalimat/ frase yang mempunyai kepentingan atau tujuan lain selain CSR pendidikan, perlu dilihat pula persentase masing-masing BUS pada kategori kalimat/ frase yang membahas mengenai CSR bidang lainnya selain pendidikan.

Pada kategori ketiga yaitu CSR bidang lainnya, persentasenya berkisar pada angka $0-50 \%$ dengan rata- rata $22,24 \%$. Persentase tertinggi dimiliki oleh Maybank Syariah yaitu sebesar 50\%. Sehingga dapat diketahui 50\% dari laporan CSR bidang pendidikannya belum benar-benar mengungkapkan mengenai CSR pendidikan, melainkan mengenai CSR bidang lainnya yang seharusnya tidak diungkapkan di dalam laporan tersebut. Asumsi tersebut didukung oleh besarnya persentase kategori kalimat/ frase yang membahas mengenai bisnis/ promosi sebesar 30\%, sehingga dapat diambil kesimpulan bahwa Maybank Syariah memang masih lemah dalam hal pengungkapan CSR bidang pendidikan. Kemudian untuk posisi BUS dengan persentase terendah dalam kategori ini, ditempati oleh BRI Syariah, Bank Panin Syariah, dan BNI Syariah. Yang mana pengungkapan mengenai CSR bidang lainnya hanya $0 \%$ dari keseluruhan laporan CSR bidang pendidikan. Artinya ketiga bank tersebut sama sekali tidak mengungkapkan kalimat/ frase yang membahas CSR selain CSR bidang pendidikan. Namun, perlu dilihat pula persentase masing-masing BUS pada kategori kalimat/ frase yang membahas mengenai bisnis/ promosi sebelum menyimpulkan kecenderungan pengungkapan dalam laporan CSR pendidikan kedua bank tersebut.

Agar dapat lebih mudah dilihat secara jelas dan detail, penjelasan diatas digambarkan dalam grafik berikut:

Grafik 3. Hasil Rekapitulasi Perhitungan UR tahun 2013

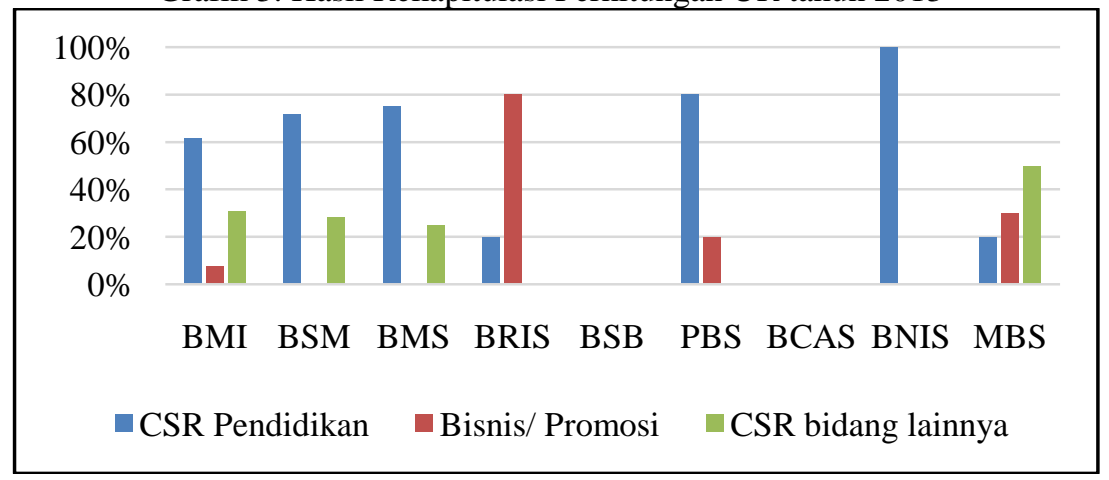

Sumber: Laporan Tahunan Bank Umum Syariah Tahun 2013

Sementara itu untuk tahun 2014, persentase kategori CSR pendidikan berkisar pada angka $0-100 \%$ dengan rata-rata $51,91 \%$. Persentase tertinggi 
dimiliki oleh BNI Syariah yang mana pengungkapan kalimat/ frase mengenai CSR bidang pendidikannya mencapai $100 \%$ dari keseluruhan Laporan CSR bidang pendidikan. Hal tersebut menunjukan bahwa dalam laporannya BNI Syariah fokus dalam hal pengungkapkan kalimat/ frase yang membahas mengenai CSR pendidikan. Tidak ditemukan kepentingan ataupun tujuan lain seperti pengungkapan kalimat/ frase mengenai bisnis/ promosi atau pun CSR bidang lainnya dalam laporan tersebut. Untuk persentase terendah dalam kategori pengungkapan kalimat/ frase mengenai CSR pendidikan, dimiliki oleh BCA Syariah yang persentasenya yaitu 0\% dari keseluruhan Laporan CSR bidang pendidikan. Artinya, laporan CSR bidang pendidikan BCA Syariah belum benar-benar mengungkapkan CSR bidang pendidikannya dan terindikasi memiliki kepentingan atau tujuan lain selain pengungkapan kalimat/ frase mengenai CSR pendidikan dalam pengungkapan laporannya.

Pada kategori kedua yaitu bisnis/ promosi, persentasenya juga berkisar pada angka $0-100 \%$. Yang mana posisi tertingginya ditempati oleh BCA Syariah yaitu sebesar $100 \%$. Melihat persentase yang sangat besar yang dimiliki BCA Syariah pada kategori bisnis/ promosi tersebut, dapat disimpulkan bahwa asumsi yang dijelaskan dalam paragraf sebelumnya adalah benar adanya. Kemudian untuk persentase terendah dalam kategori bisnis/ promosi, dimiliki oleh 4 BUS yaitu Bank Syariah Mandiri, Bank Panin Syariah, BNI Syariah, dan Maybank Syariah. Persentase kalimat/ frase yang membahas mengenai bisnis/ promosi pada keempat BUS tersebut adalah 0\% dari keseluruhan laporan CSR bidang pendidikan. Artinya tidak ditemukan kalimat/ frase yang cenderung membahas bisnis/ promosi. Namun, perlu dilihat pula persentase masing-masing BUS pada kategori kalimat/ frase yang membahas mengenai CSR bidang lainnya selain pendidikan sebelum menyimpulkan kecenderungan pengungkapan dalam laporan CSR pendidikan keempat bank tersebut.

Selanjutnya untuk kategori CSR bidang lainnya, persentasenya berkisar pada angka 0-64,29\%. Yang mana persentase tertinggi dimiliki oleh Bank Panin Syariah yaitu 64,29\%. Angka tersebut tentunya cukup besar dan mengindikasikan bahwa dalam laporan CSR pendidikannya, Bank Panin Syariah masih dianggap lemah dalam mengungkapkan kalimat/ frase yang benar- benar membahas mengenai CSR bidang pendidikan. Sedangkan persentase terendah dimiliki oleh 4 BUS yaitu BRI Syariah, Bank Syariah Bukopin, BCA Syariah, dan BNI Syariah. Masing- masing dari BUS tersebut mengungkapkan kalimat/ frase mengenai CSR bidang lainnya sebesar 0\% dari keseluruhan laporan CSR pendidikan. Namun sebelum menyimpulkan kecenderungan pengungkapan dalam laporan CSR pendidikan keempat BUS tersebut, perlu dilihat pula persentase masing-masing BUS pada kategori kalimat/ frase yang membahas mengenai bisnis/ promosi selain pendidikan.

Agar dapat lebih mudah dilihat secara jelas dan detail, penjelasan diatas digambarkan dalam grafik berikut: 
Grafik 4. Hasil Rekapitulasi Perhitungan UR tahun 2014

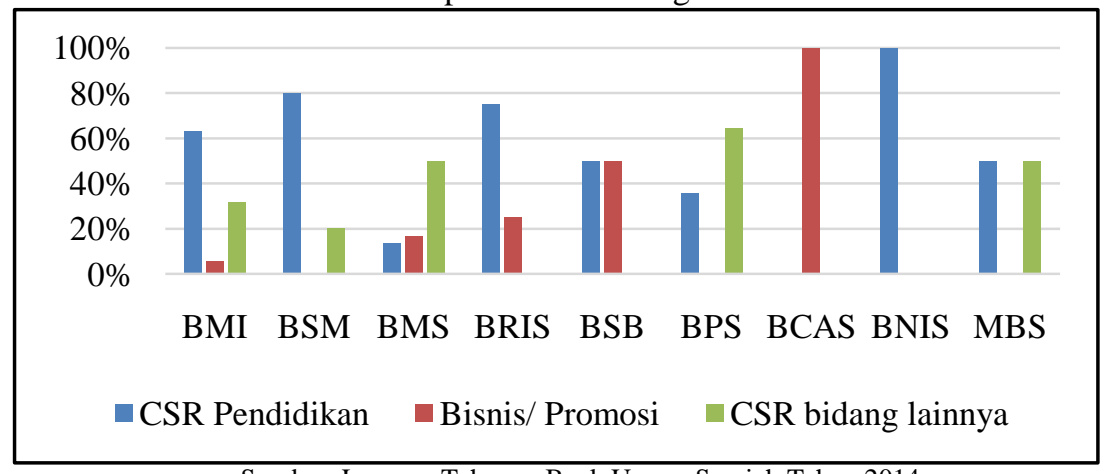

Sumber: Laporan Tahunan Bank Umum Syariah Tahun 2014

\section{KESIMPULAN}

Berdasarkan hasil analisis dan pembahasan pada bab IV, dapat disimpulkan bahwa tiap BUS memiliki luas pengungkapan yang berbeda baik pengungkapan CSR secara keseluruhan maupun pengungkapan yang membahas mengenai pendidikan. Pada tahun 2013 saja, rentang jumlah kalimat/ frase mengenai CSR yang diungkapkan dalam Laporan Tahunan masing- masing BUS cukup jauh yaitu berkisar pada 9-194 kalimat/ frase, dan yang membahas mengenai pendidikan berkisar pada 0-13 kalimat/ frase. Sementara pada tahun 2014, kalimat/ frase mengenai CSR yang diungkapkan dalam laporan tahunan masing- masing BUS berkisar pada 10-151 kalimat/ frase, dan yang membahas mengenai pendidikan berkisar pada 1-19 kalimat/ frase.

\section{DAFTAR PUSTAKA}

Baydoun, N., \& Wilett, R. (2000). Islamic Corporate Reports. Abacus.

Beekun, R. I. (1997). Islamic Business Ethict, Virginia: International Institute of Islamic Thought.

Darwin, A. (Pemain). (2004, Desember 13-15). Penerapan Sustainibility Reporting di Indonesia. Konvensi Nasional Akuntansi V, Program Profesi Lanjutan, Yogyakarta.

Disdikpora. (2014, Mei 14). Kualitas Pendidikan Indonesia Ranking 69 Tingkat Dunia. Diambil kembali dari Disdikpora: http://disdikpora.palangkaraya.go.id/berita-160-kualitas-pendidikanindonesia-ranking-69-tingkat-dunia.html

Elkington, J. (1998). Cannibals With Forks: The Triple Bottom Line in 21st Century Business.

Farook, S., Hassan, M., \& Lanis, R. (2011). Determinants of Corporate Social Responsibility Disclosure: The Case of Islamic Banks. Islamic Accounting and Business Research, 114-141. 
Fleishman. (2007). "Rethingking Corporate Social Responsibility" (Www.fleishman.com).

Kemendikbud. (2012, Februari 12). Berita Buruk Pendidikan Indonesia. Diambil kembali dari Kemendikbud: http://kemdikbud.go.id/kemdikbud/berita/3574

Kotler, P., \& Lee, N. (2005). Corporate Social Responsibility - Doing The Most Good for Your Company and Your Cause.

Kripendoff, K. (1991). Analisis Isi Pengantar Teori dan Metodologi. Jakarta: Rajawali Press .

Mentari, R. A. (t.thn.). Impelementasi Corporate Social Responsibility Pada Pendidikan. E-Journal Universitas Negeri Surabaya.

Naqvy, S. N. (1996). Etika dan Ilmu Ekonomi Suatu Sintesa Islam. Bandung: Mizan.

Naraduhita, D. C., \& Sawarjuwono, T. (2012). Coorporate Social Responsibility : Upaya Memahami Alasan Dibalik Pengungkapan CSR Bidang Pendidikan. Jurnal Akuntansi \& Auditing .

Oktarizal, M. A., Triyuwono, I., \& Achsin, M. (2014). Makna Corporate Social Responsibility Bagi Manajemen Pabrik Gula PT Kebun Agung (Malang, Jawa Timur). Jurnal Aplikasi Manajemen, 23.

Rahman, R. (2009). Corporate Social Responsibility: Antara Teori dan Kenyataan. Jakarta: PT. Buku Kita.

Rakyat, P. (2012, Desember 16). 87 Persen Dana CSR BRI untuk Sektor Pendidikan. Diambil kembali dari Pikiran Rakyat: http://www.pikiranrakyat.com/ekonomi/2012/12/16/215330/87-persen-dana-csr-briuntuk-sektor-pendidikan

Sopyan, Y. (2014). Corporate Social Responsibility (CSR) Sebagai Implementasi Fikih Sosial Untuk Pemberdayaan Masyarakat.

Wibisono, Y. (2007). Membedah Konsep dan Aplikasi CSR. Gresik: Fascho Publishing. 